\title{
In vivo biomimetic calcification of selected organic scaffolds using snail shell regeneration: a new methodological approach
}

\author{
Tomasz Machałowski ${ }^{1,2}$ (D) Marcin Wysokowski ${ }^{1,2} \cdot$ laroslav Petrenko ${ }^{2} \cdot$ Enrico Langer $^{3} \cdot$ Dmitry Tsurkan $^{4}$. \\ Teofil Jesionowski ${ }^{1} \cdot$ Hermann Ehrlich ${ }^{2}$
}

Received: 12 April 2020 / Accepted: 14 May 2020

(c) The Author(s) 2020

\begin{abstract}
In vivo biomimetic biomineralization using living organisms known as biomineralizers is currently a major research trend. Industrially cultivated terrestrial snails, such as the common garden snail Cornu aspersum, represent a simple model organism that is ideal for use in experiments on the regeneration of the calcified shell after the excavation of a corresponding shell fragment. The mollusk's artificially damaged shell is regenerated via the formation of an organic regenerative membrane, which serves as a native template for in vivo biocalcification. In this study, for the first time, a special plexiglass device for non-lethal fixation of living snails, enabling real-time monitoring of their ability to regenerate their shells using digital microscopy, has been proposed and tested. As an alternative to natural biomineralization using the mollusk's own sources, we propose chitin- and collagen-based templates, which have been shown to be effectively calcified by living snails. The results indicate that the type of organic template used for in vivo biomineralization has a substantial effect on the nature of the mineral phases.
\end{abstract}

Keywords In vivo biomineralization $\cdot$ Biomimetics $\cdot$ Shell regeneration $\cdot$ Chitin $\cdot$ Collagen $\cdot$ Scaffolds $\cdot$ Cornu aspersum

\section{Introduction}

The phylum Mollusca, with around 200,000 living species [1], represents a vast group of invertebrate animals exhibiting great diversity in terms of ecology, behavior and morphology [2]. In recent years, there has been increasing interest in mollusks in such fields as food production, cosmetics and biomedicine [1, 3-6]. Mollusks are regarded as

Tomasz Machałowski

tomasz.g.machalowski@doctorate.put.poznan.pl

Teofil Jesionowski

teofil.jesionowski@put.poznan.pl

$\triangle$ Hermann Ehrlich

hermann.ehrlich@esm.tu-freiberg.de

1 Institute of Chemical Technology and Engineering, Faculty of Chemical Technology, Poznan University of Technology, 60965 Poznan, Poland

2 Institute of Electronics and Sensor Materials, TU Bergakademie Freiberg, 09599 Freiberg, Germany

3 Institute of Semiconductors and Microsystems, 01062 Dresden, TU, Germany

4 TissueGUARD GmbH, 01217 Dresden, Germany unmatched specialists in the formation of calcium carbonatebased shells [7-10]. Recently, particular attention has been paid to applications of terrestrial mollusks and their hemolymph as sources for the development of bioinspired composites using a biomimetic strategy $[9,11,12]$. For example, the biomimetic creation of calcium carbonate deposits by the imitation of such naturally occurring processes as shell regeneration using external templates (i.e., selective metal or organic implants) may significantly improve the biointegration of such constructs with human cells. On the other hand, the formation of biominerals by mollusks has the potential to inspire the design of new composite-based materials, especially those fabricated under mild biomimetic conditions [13]. It has been shown that $\mathrm{CaCO}_{3}$-based scaffolds have positive effects in relation to the adhesion, growth and proliferation of osteoblasts and other cells applicable in regenerative medicine [14-16]. Selected forms of biogenic calcium carbonate-calcite, aragonite or amorphous calcium carbonate (ACC) — display a strong predisposition for biomedical applications due to their biocompatibility [15, 17], biodegradability $[16,18]$ and osteoinductive properties $[14,19]$. As recently reported Woldetsadik, cells growing on calcium carbonate scaffolds produce higher levels 
of transforming growth factor beta (TGF- $\beta$ ) and vascular endothelial growth factor $A$ (VEGF- $A$ ), which play a key role in the regulation of osteoblast differentiation [20]. A recent study [21] indicates that a $\mathrm{CaCO}_{3}$ layer used to coat a titanium implant may significantly improve and accelerate the growth of bone and osseointegration at the early healing phase, leading to reduced clinical healing times and increased success of implantation. It is well recognized that, for example, in human bone, ACC is also a precursor for crystalline carbonated apatite and has osteogenic potential $[19,22]$.

Chitin and collagen have been recognized as excellent templates and scaffolds for the development of a broad variety of composite materials $[8,10,23-38]$ due to their biocompatibility and biodegradability. In our recent studies [11, 12], a new method for obtaining calcium carbonate deposition ex vivo has been described, using hemolymph isolated from the living common garden snail Cornu aspersum on 3D chitinous scaffolds of marine sponge origin. Here, we present a non-lethal methodological approach involving fixation of living mollusks within a special device, with the aim of performing stereo microscopic observation of in vivo biomimetic calcification using the natural ability of the snail to regenerate its shell over time. Furthermore, for the first time, a 3D chitinous scaffold isolated from the marine demosponge Aplysina archeri and a collagen-based biomaterial were used as organic substrata for biomimetic mineralization using living mollusks.

\section{Materials and methods}

\subsection{Supply and keeping of Cornu aspersum snails.}

Adult specimens of the terrestrial snail Cornu aspersum (O.F. Müller, 1774) were supplied by a commercial heliciculture farm (Helixpol, Małszyce, Poland). The snails were kept in a glass aquarium $(40 \times 40 \mathrm{~cm})$ at room temperature. Their diet consisted of fresh lettuce, carrots and apples, supplemented by cuttlebone of Sepia officinalis as a calcium carbonate $\left(\mathrm{CaCO}_{3}\right)$ source. The snails were kept moist throughout the experimental period with wet humus. An animal welfare and rights statement is not required.

\subsection{Organic scaffolds}

Air-dried specimens of $A$. archeri marine demosponges were supplied by BromMarin GmbH (Freiberg, Germany). Chitinous scaffolds were obtained by chemical treatment of the specimens as described in our previous work [39-41]. First, selected fragments of $A$. archeri skeleton were immersed in deionized water for $1 \mathrm{~h}$ to remove water-soluble compounds. Next, demineralization of the skeletons was carried out by treatment with $20 \%$ acetic acid (Sigma-Aldrich, St. Louis, Missouri, USA) for $4 \mathrm{~h}$ at room temperature. Subsequently, $2.5 \mathrm{M} \mathrm{NaOH}$ (Sigma-Aldrich, St. Louis, Missouri, USA) solution was applied as a deproteinization agent, for $12 \mathrm{~h}$ at $37^{\circ} \mathrm{C}$. The procedure of demineralization and deproteinization was repeated until soft and fully transparent $3 \mathrm{D}$ chitinous scaffolds were obtained [41]. Finally, the 3D chitinous scaffolds were neutralized using distilled water and stored at $4{ }^{\circ} \mathrm{C}$.

The collagen used in this study was the commercially available wound dressing material known as Suprasorb C (Lohmann \& Rauscher, Neuwied, Germany). The Suprasorb $\mathrm{C}$ collagen dressing consists of bovine skin collagen.

\subsection{Non-lethal snail shell regeneration procedure}

First, the shell surface of the selected C. aspersum snail was cleaned with $70 \%$ ethanol (Th. Geyer GmbH \& Co. KG, Renningen, Germany). Regeneration was initiated by removing a fragment of the upper part of the shell, approximately $3 \mathrm{~mm}$ in diameter (Fig. 2a). This procedure has previously been used as part of a non-lethal method of hemolymph collection [11, 12, 42, 43] and for obtaining a description of shell regeneration [44]. Next, the area of injury was left uncovered (as a reference sample) or covered with pure chitinous scaffold and collagen scaffold, which served as organic substrata for crystal deposition during in vivo repair. After $24 \mathrm{~h}$, the naturally appearing regenerative membranes and in vivo developed biocomposites were analyzed. During the months after the procedure, the snails used in the study did not exhibit any visible changes in either physiology or behavior.

\subsection{Device for the mollusk fixation.}

A novel plexiglass-based device was designed (Fig. 1) and fabricated for fixation of the living $C$. aspersum snails, with the aim of carrying out observation of their shell regeneration in real time using a digital microscope. The device was designed with the goal of ensuring optimum stress-free conditions for the animals during the experiment. Despite being immobilized within the device, the snails had constant access to water and food during the study.

\subsection{Digital, light and fluorescence microscopy}

The samples were observed and analyzed with the use of an advanced imaging and measurement system consisting of a VHX-6000 (Keyence, Osaka, Japan) digital optical microscope and VH-Z20R swing-head zoom lenses (magnification up to $200 \times$ ). 
Fig. 1 Sketch of the plexiglass device for fixation of living $C$. aspersum snails to enable realtime monitoring of their shell regeneration using a digital microscope. Scale bar $1 \mathrm{~cm}$
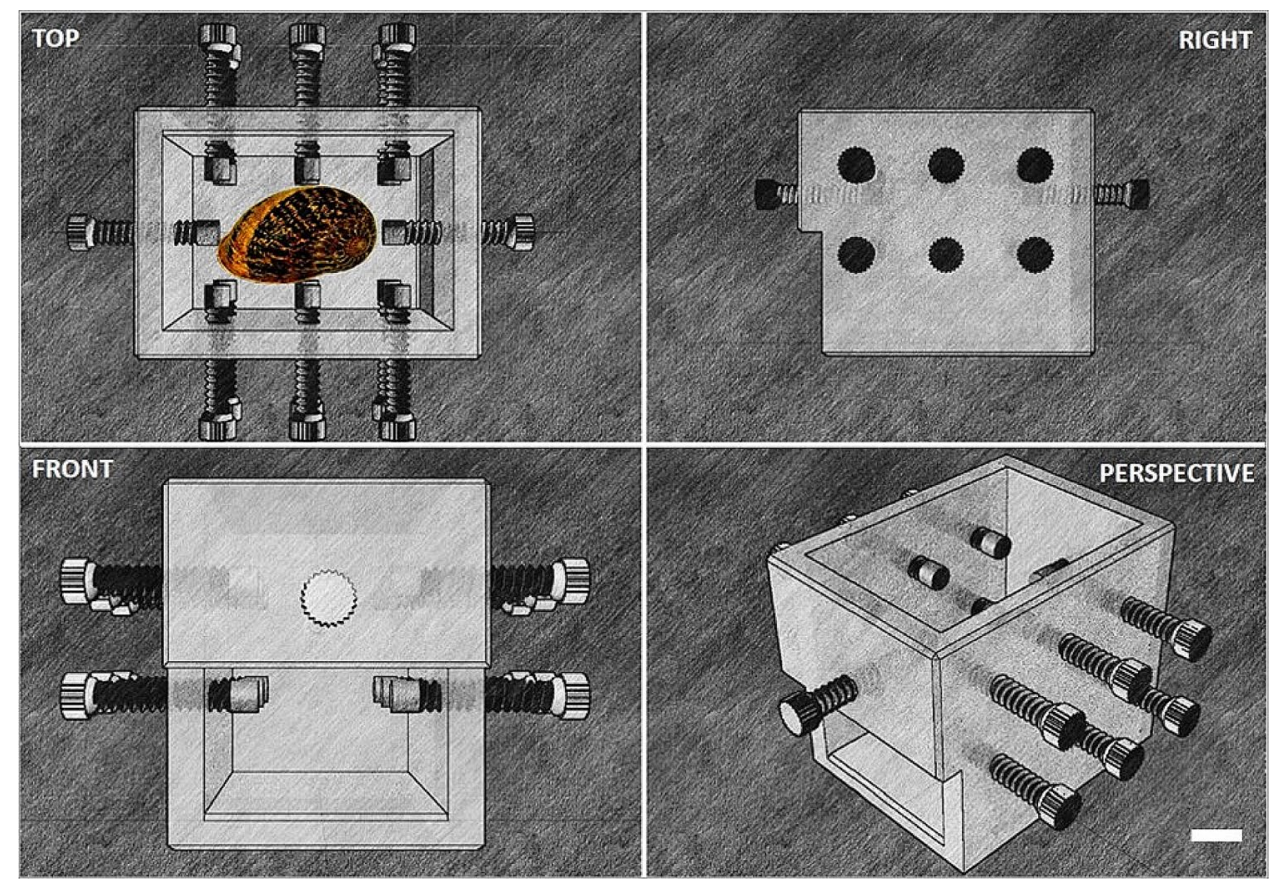

\subsection{Infrared spectroscopy}

Attenuated total reflectance Fourier transform infrared spectroscopy (ATR-FTIR) was used for qualitative characterization and identification of the isolated materials. The analysis was performed using a Nicolet $210 \mathrm{c}$ spectrometer (Thermo Fisher Scientific, Waltham, Massachusetts, USA).

\subsection{Scanning electron microscopy}

The microstructure was determined using the S4700 (Hitachi, Tokio, Japan) and XL 30 ESEM (Fa. Philips Electron Optics, Hillsboro, Oregon, USA) scanning electron microscopes. Samples were dried and covered with Au using a Cressington Sputter Coater S150B (BOC Edwards, Wilmington, Massachusetts, USA).

\section{Results and discussion}

The mineralized shell of mollusks is essential for their survival; it is often the only specialized structure protecting their soft body against predators and adverse environmental factors [45]. Proteins constitute only a small percentage of the biomineral, but they are directly involved in the control of biomineralization. Although more than $95 \%$ of the shell is composed of calcium carbonate, and the organic matrix constitutes only $<5 \%$, this small chemical content gives the shell a strength 3000 times that of monolithic $\mathrm{CaCO}_{3}$ [46]. The small amount of organic matrix not only reinforces the mechanical properties of the biomineral, but also plays a key role in control of the mineralization process, determining the size and morphology of the crystals, specific crystallographic orientation, polymorph or amorphous phase stabilization, and/or crystal growth inhibition [44, 47, 48]. A crucial aspect in understanding the biological basis of mollusk biomineralization is understanding of the naturally occurring shell damage repair process, which involves in vivo re-mineralization of the wound [49].

In this study, natural shell regeneration (Fig. 2) was carried out in addition to in vivo biomimetic regeneration using selected organic templates (Fig. 3). Selected snails were placed in the device (Fig. 1) and gently fixed with plastic screws. Samples from the natural snail shell repair process were obtained from the uncovered hole, where the exposed mantle began to form new shell material after $3 \mathrm{~h}$ in the form of a regenerative membrane with subsequent calcification. After three days, the shell wound was completely covered with a mineralized layer. All snails used in this study showed no visible changes in physiology or behavior during their immobilization. All of the organisms survived six months after the experiments.

Samples observed after $24 \mathrm{~h}$ of shell repair using inserted chitin and collagen scaffolds displayed the typical elemental composition of $\mathrm{CaCO}_{3}$ (Fig. 3f, i). The presence of calcium carbonate deposits was confirmed by FTIR spectroscopy.

In a past study [49], minute crystal formation was observed in the snail Helix pomatia (Gastropoda). $\mathrm{X}$-ray diffraction analysis showed that at an early stage the crystals represented aragonite, but the formation of calcite crystals was observed in the next formed layers. Two explanations were proposed for this: the possible 
Fig. 2 Results of natural shell regeneration by a $C$. aspersum snail fixed in the device (Fig. 1). A wound obtained by removal of a fragment of the upper part of the shell is well visible under digital microscope (a). The transparent organic membrane begins to appear over the wound after $3 \mathrm{~h} \mathrm{(b).} \mathrm{The}$ mineralized layer first becomes visible due to the "turbidity" of the regenerative membrane about $6 \mathrm{~h}$ after removal of the original shell fragment (c). The in vivo biomineralization of the regenerative membrane proceeds $(\mathbf{d}, \mathbf{e})$ until observation of a fully mineralized original snail organic matrix after three days (f).
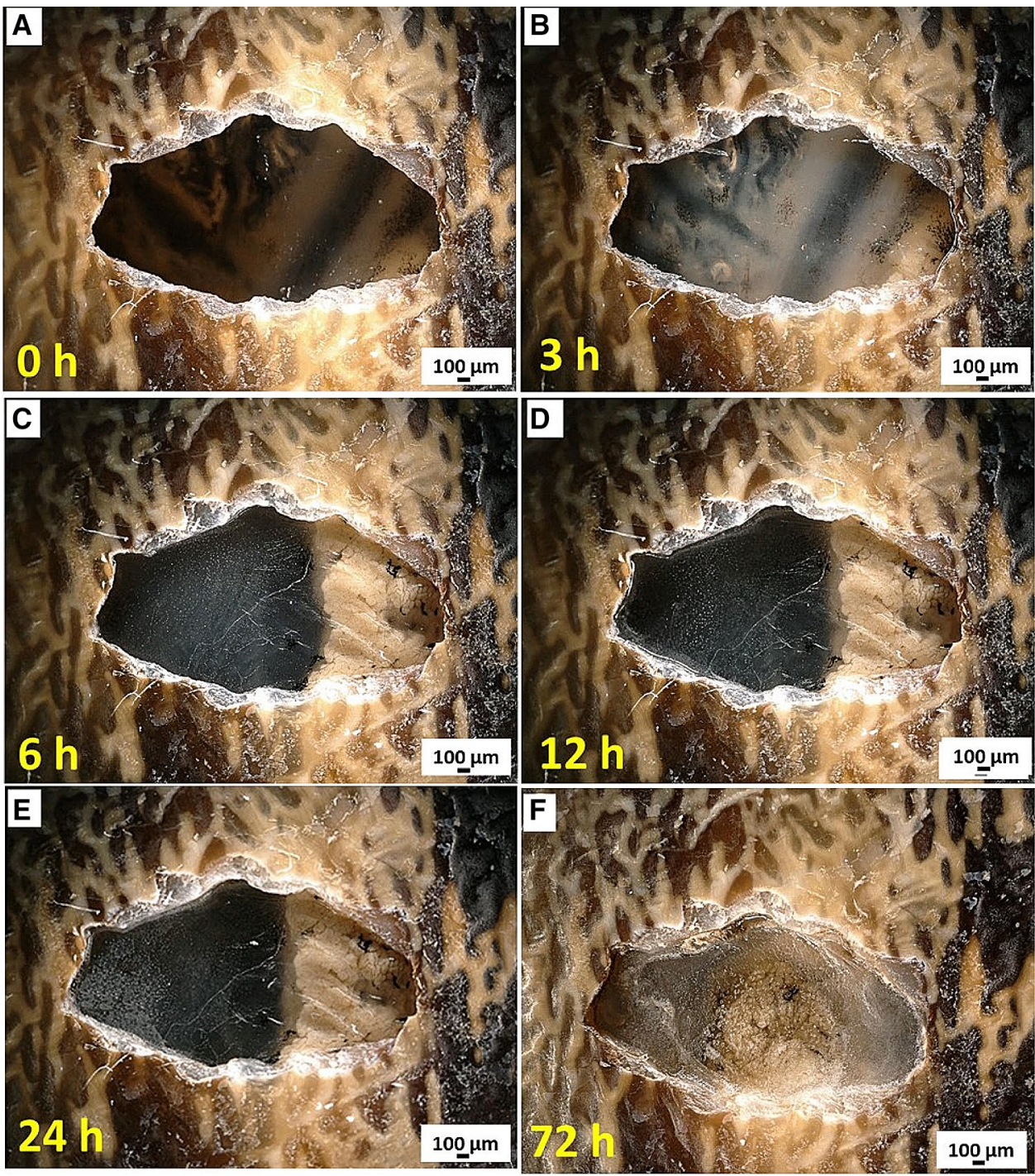

conversion of aragonite to calcite and (more probably) environmental changes during crystal formation that cause a change in the crystals' form. The same observations were recorded in our study with respect to the formation of aragonite crystals (Fig. 4b). We observed that, in contrast to the naturally occurring shell regeneration process in $C$. aspersum (Figs. 2 and $3 \mathrm{a}-\mathrm{c}$ ), the use of chitin and collagen organic templates makes it possible to obtain only calcite deposits in the first regenerative layer (Fig. 5). Similar observations have previously been reported by other researchers (for details see [44, 50]. Those authors have noted that the external matrix has a crucial influence on the formation of corresponding calcium carbonate-based crystal polymorphs, especially at the initial stage of in vivo biomineralization.

\section{Conclusions}

Biomimetics is currently well on track as a powerful approach for the generation of new composite materials and as a milestone for modern biologically inspired materials chemistry, including applied biomineralogy. The field has gained great attention, especially where there is a need for the development of novel, advanced functional materials which feature 3D morphology and hierarchical, nanostructured organization using biomineralizing invertebrates. The strategy of using industrially cultivated mollusks, both aquatic and terrestrial, for the purpose of in vivo biomineralization offers great potential. The nonlethal methodological approach presented in this study opens up a key path for the use of living snails to fabricate 

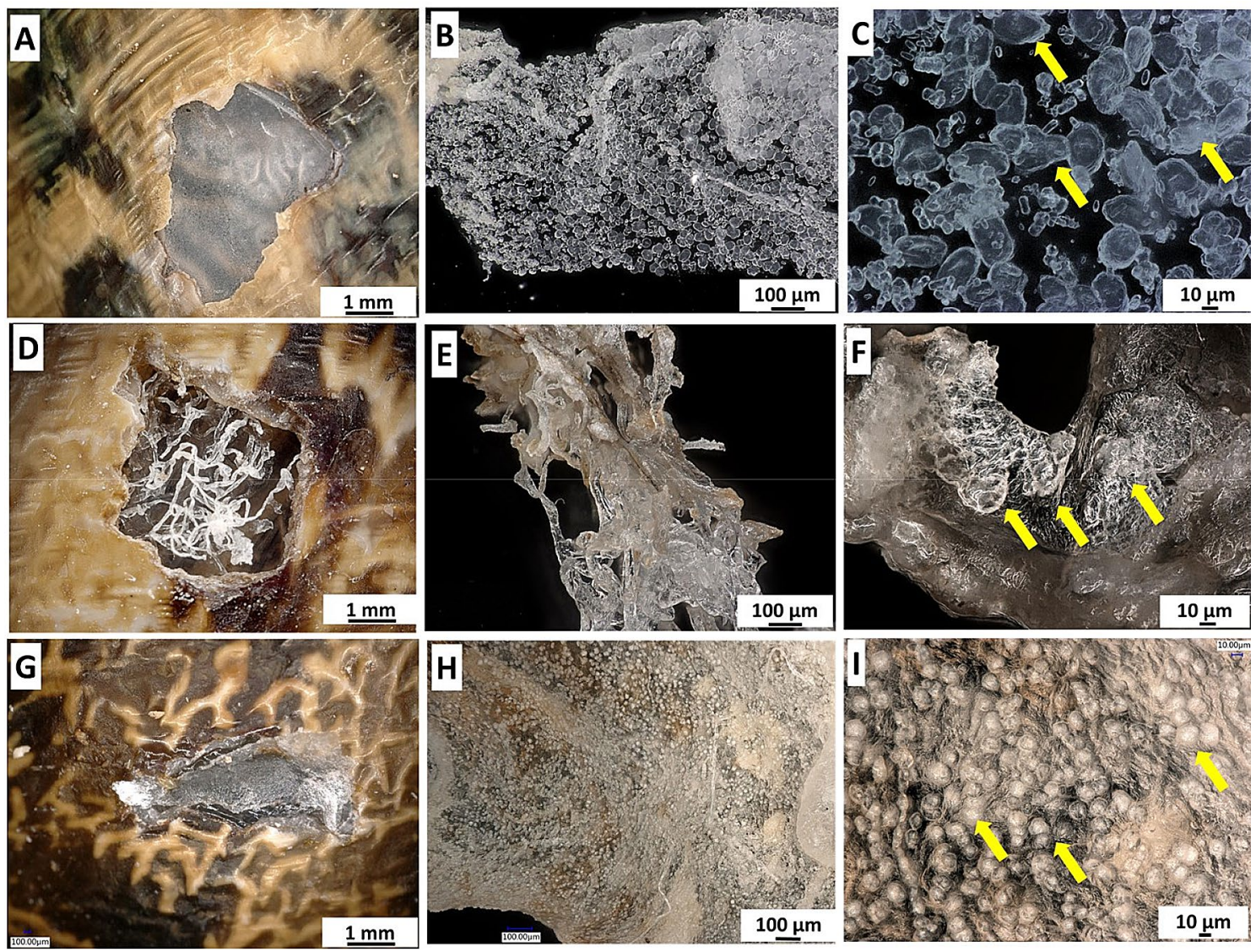

Fig. 3 Regeneration of the mechanically damaged shell of $C$. aspersum fixed in the device becomes visual under digital microscope due to development of regenerative membrane (a). This originally occurring membrane is mineralized with calcium carbonate $(\mathbf{b}, \mathbf{c})$. Chitinous 3D scaffold, used as a template, which fills the aperture in the shell (d) also becomes uniquely mineralized in vivo (e, f). Similarly, collagen scaffold (g) can be used as a proteinaceous template for in vivo calcification $(\mathbf{h}, \mathbf{i})$. Calcium carbonate $\left(\mathrm{CaCO}_{3}\right)$ deposits are marked with yellow arrows 
Fig. 4 FTIR spectrum a of the natural C. aspersum shell regenerative membrane, displaying strong similarity to Sepia officinalis cuttlebone, considered as an aragonite-chitin biocomposite-based construct [51]. SEM image $\mathbf{b}$ of the regenerative C. aspersum shell membrane $24 \mathrm{~h}$ after injury, showing crystals with a morphology typical of aragonite [52]
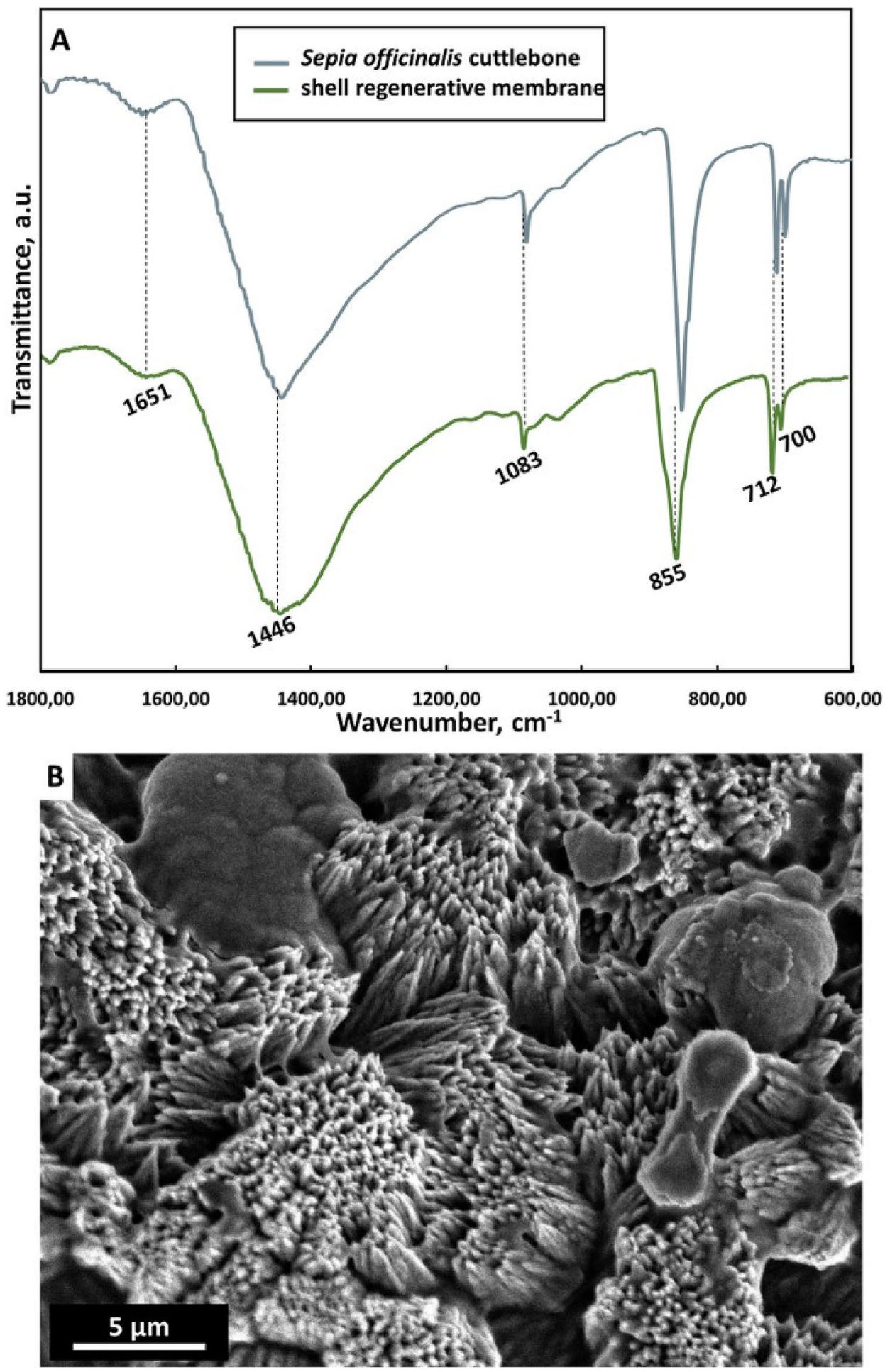
Fig. 5 FTIR spectra of in vivo biomimetically obtained mineralized chitinous (a) and collagen (b) templates (Fig. 3) after $24 \mathrm{~h}$ of experiment. Spectra indicate the presence of the calcite polymorph in both cases. Calcium carbonate crystals with a morphology typical of the calcite polymorph [52] were observed to be deposited on the 3D chitinous scaffold (SEM image, c)

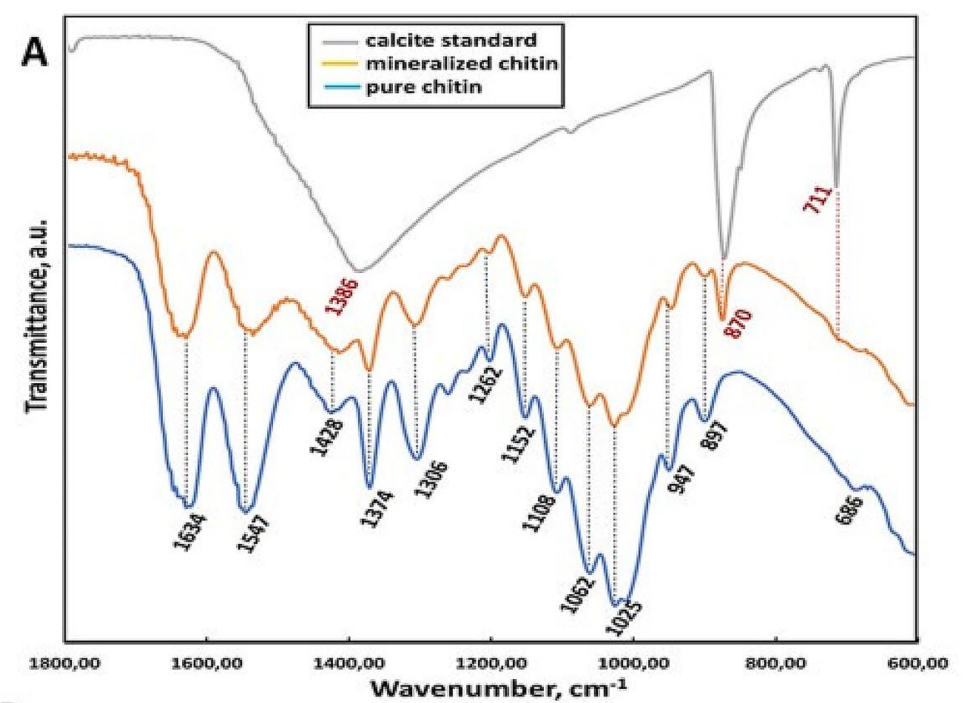

B

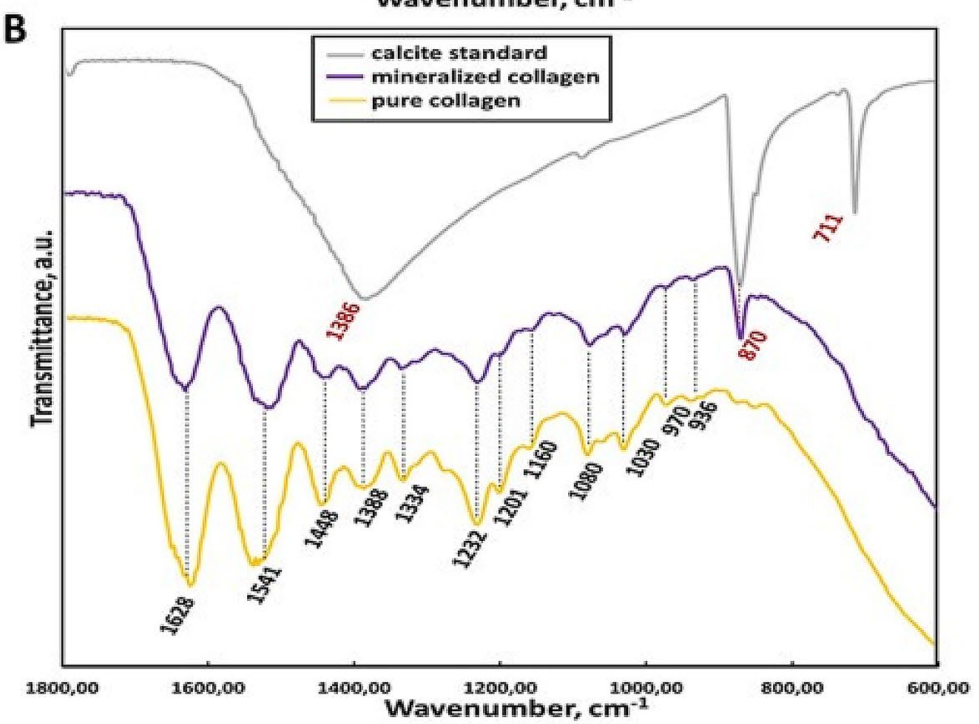

C

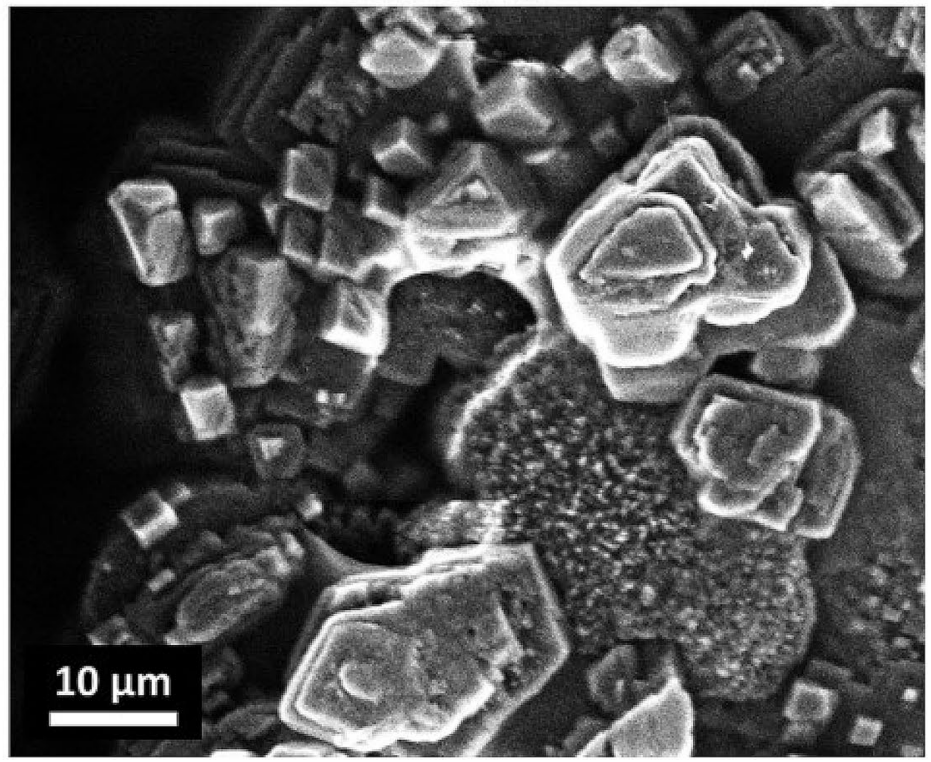


mineral-based composites for future applications in tissue engineering and regenerative medicine.

Funding This work was partially supported by DFG Project HE 394/3, SMWK Project no. 02010311 (Germany) and by the Ministry of Science and Higher Education (Poland) (TJ, TM, MW). Marcin Wysokowski is financially supported by the Polish National Agency for Academic Exchange (PPN/BEK/2018/1/00071). Tomasz Machałowski is supported by DAAD (personal ref. no. 91734605).

\section{Compliance with ethical standards}

Conflict of interest The authors declare that there is no conflict of interests regarding the publication of this manuscript.

Informed consent All of the coworkers have agreed to participate.

Open Access This article is licensed under a Creative Commons Attribution 4.0 International License, which permits use, sharing, adaptation, distribution and reproduction in any medium or format, as long as you give appropriate credit to the original author(s) and the source, provide a link to the Creative Commons licence, and indicate if changes were made. The images or other third party material in this article are included in the article's Creative Commons licence, unless indicated otherwise in a credit line to the material. If material is not included in the article's Creative Commons licence and your intended use is not permitted by statutory regulation or exceeds the permitted use, you will need to obtain permission directly from the copyright holder. To view a copy of this licence, visit http://creativecommons.org/licenses/by/4.0/.

\section{References}

1. J.A. Fernandez Robledo, R. Yadavalli, A. Bassem, E. PalesEspinosa, M. Gerdol, S. Greco, R.J. Stevick, M. Gómez-Chiarr, Y. Zhang, C.A. Heil, A.N. Tracy, D. Bishop-Bailey, M.J. Metzger, Dev. Comp. Immunol. 92, 260-282 (2019)

2. V.J. Smith, A. Accorsi, D. Malagoli, in The Evolution of the Immune System. Conservation and Diversification, ed. by M. Davide (Elsevier Inc, Amsterdam, 2016), pp. 1-28

3. E.A. Pila, J.T. Sullivan, X.Z. Wu, J. Fang, S.P. Rudko, M.A. Gordy, P.C. Hanington, Dev. Comp. Immunol. 58, 119-128 (2016)

4. F.S. Ferreira, H. Albuquerque, U.P.D.M. Coutinho, R.R. de Oliveira Almeida, W. da Nobrega Alves, Altern. Med. 2012, 1-20 (2012)

5. Y. Song, C. Cao, R. Qiu, J. Hu, M. Liu, S. Lu, H. Shi, K.M. Raley-Susman, D. He, Environ. Pollut. 250, 447-455 (2019)

6. C.-J. Kao, H.-Y. Chou, Y.-C. Lin, Q. Liu, H.-M.D. Wang, Antioxidants 8, 533 (2019)

7. M.J. Connors, H. Ehrlich, M. Hog, C. Godeffroy, S. Araya, I. Kallai, D. Gazit, M. Boyce, C. Ortiz, J. Struct. Biol. 177, 314-328 (2012)

8. M. Wysokowski, M. Zatoń, V.V. Bazhenov, T. Behm, A. Ehrlich, A.L. Stelling, M. Hog, H. Ehrlich, Paleobiology 40, 529-540 (2014)

9. M.B. Johnstone, N.V. Gohad, E.P. Falwell, D.C. Hansen, K.M. Hansen, A.S. Mount, J. Exp. Mar. Bio. Ecol. 463, 8-16 (2015)

10. H. Ehrlich, Int. Geol. Rev. 52, 661-699 (2010)

11. M. Wysokowski, T. Machałowski, I. Petrenko, C. Schimpf, D. Rafaja, R. Galli, J. Zietek, S. Pantovic, A. Voronkina, V.K.V.N.
Ivanenko, B.W. Hoeksema, C. Diaz, Y. Khrunyk, A.L. Stelling, M. Giovine, T. Jesionowski, H. Ehrlich, Mar. Drugs 18, 123 (2020)

12. K. Nowacki, I. Stępniak, T. Machalowski, M. Wysokowski, I. Petrenko, C. Schimpf, D. Rafaja, J. Ziętek, S. Pantović, A. Voronkina, V. Kovalchuk, V. Ivanenko, Y. Khrunyk, R. Galli, Y. Joseph, M. Gelinsky, T. Jesionowski, H. Ehrlich, Appl Phys A accepted 126, 368 (2020)

13. J. Seto, Advanced topics in biomineralization (InTech, Rijeka, 2012)

14. B. Kruppke, J. Farack, S. Weil, E.D. Aflalo, D. Polakova, A. Sagi, T. Hanke, J. Biomed. Mater. Res. 108, 694-708 (2019)

15. S. Biradar, P. Ravichandran, R. Gopikrishnan, V. Goornavar, J.C. Hall, V. Ramesh, S. Baluchamy, R.B. Jeffers, G.T. Ramesh, J. Nanosci. Nanotechnol. 11, 6868-6874 (2011)

16. Y. Fujita, T. Yamamuro, T. Nakamura, S. Kotani, C. Ohtsuki, T. Kokubo, J. Biomed. Mater. Res. 25, 991-1003 (1991)

17. H. Bahrom, A.A. Goncharenko, L. Fatkhutdinova, O. Peltek, A. Muslimov, O. Koval, I.E. Eliseev, A. Manchev, D. Gorin, I.I. Shishkin, R.E. Noskov, A.S. Timin, P. Ginzburg, M.V. Zyuzin, A.C.S. Sustain, Chem. Eng. 7, 19142-19156 (2019)

18. D. Geblinger, B. Geiger, L. Addadi, ChemBioChem 10, 158-165 (2008)

19. E. Tolba, W.E.G. Müller, B.M. Abd El-Hady, M. Neufurth, F. Wurm, S. Wang, H.C. Schröder, X. Wang, J. Mater. Chem. 4, 376-386 (2016)

20. A.D. Woldetsadik, S.K. Sharma, S. Khapli, R. Jagannathan, M. Magzoub, A.C.S. Biomater, Sci. Eng. 3, 2457-2469 (2017)

21. Y. Liu, Y. Zhou, T. Jiang, Y. De Liang, Z. Zhang, Y.N. Wang, Int J. Oral Sci. 9, 133-138 (2017)

22. X. Wang, H.C. Schröder, W.E.G. Müller, Trends Biotechnol. 32, 441-447 (2014)

23. H. Ehrlich, T. Douglas, D. Scharnweber, T. Hanke, R. Born, S. Bierbaum, H. Worch, Zeitschrift fur anorg. und allg. Chemie 631, 1825-1830 (2005)

24. H. Ehrlich, D. Janussen, P. Simon, V.V. Bazhenov, N.P. Shapkin, C. Erler, M. Mertig, R. Born, S. Heinemann, T. Hanke, H. Worch, J.N. Vournakis, J. Nanomater. 2008, 1-8 (2008)

25. H. Ehrlich, S. Heinemann, C. Heinemann, P. Simon, V.V. Bazhenov, N.P. Shapkin, R. Born, K.R. Tabachnick, T. Hanke, H. Worch, J. Nanomater. 2008, 1-8 (2008)

26. H. Ehrlich, T. Hanke, P. Simon, R. Born, C. Fischer, A. Frolov, T. Langrock, R. Hoffmann, U. Schwarzenbolz, T. Henle, V.V. Bazhenov, H. Worch, J. Biomed. Mater. Res.-Part B Appl. Biomater. 92, 542-551 (2010)

27. S. Heinemann, C. Heinemann, H. Ehrlich, M. Meyer, H. Baltzer, H. Worch, T. Hanke, Adv. Eng. Mater. 9, 1061-1068 (2007)

28. S. Heinemann, H. Ehrlich, C. Knieb, T. Hanke, Int. J. Mater. Res. 98, 603-608 (2007)

29. T. Jesionowski, M. Norman, S. Zółtowska-Aksamitowska, I. Petrenko, Y. Joseph, H. Ehrlich, Mar. Drugs 16, 88 (2018)

30. H. Ehrlich, M. Wysokowski, S. Zółtowska-Aksamitowska, I. Petrenko, T. Jesionowski, Mar. Drugs 16, 79 (2018)

31. V.V. Mutsenko, O. Gryshkov, L. Lauterboeck, O. Rogulska, D.N. Tarusin, V.V. Bazhenov, K. Schütz, S. Brüggemeier, E. Gossla, A.R. Akkineni, H. Meißner, A. Lode, S. Meschke, J. Fromont, A.L. Stelling, K.R. Tabachnik, M. Gelinsky, S. Nikulin, S. Rodin, A.G. Tonevitsky, A.Y. Petrenko, B. Glasmacher, P.J. Schupp, H. Ehrlich, Int. J. Biol. Macromol. 104, 1955-1965 (2017)

32. V.V. Mutsenko, V.V. Bazhenov, O. Rogulska, D.N. Tarusin, K. Schütz, S. Brüggemeier, E. Gossla, A.R. Akkineni, H. Meißner, A. Lode, S. Meschke, A. Ehrlich, S. Petović, R. Martinović, M. Djurović, A.L. Stelling, S. Nikulin, S. Rodin, A. Tonevitsky, M. Gelinsky, A.Y. Petrenko, B. Glasmacher, H. Ehrlich, Int. J. Biol. Macromol. 104, 1966-1974 (2017) 
33. V. Kovalchuk, A. Voronkina, B. Binnewerg, M. Schubert, L. Muzychka, M. Wysokowski, M.V. Tsurkan, N. Bechmann, I. Petrenko, A. Fursov, R. Martinovic, V.N. Ivanenko, J. Fromont, O.B. Smolii, Y. Joseph, M. Giovine, D. Erpenbeck, M. Gelinsky, A. Springer, K. Guan, S.R. Bornstein, H. Ehrlich, Mar. Drugs 17, 574 (2019)

34. K. Spinde, M. Kammer, K. Freyer, H. Ehrlich, J.N. Vournakis, E. Brunner, Chem. Mater. 23, 2973-2978 (2011)

35. M. Wysokowski, M. Motylenko, J. Walter, G. Lota, J. Wojciechowski, H. Stöcker, R. Galli, A.L. Stelling, C. Himcinschi, E. Niederschlag, E. Langer, V.V. Bazhenov, T. Szatkowski, J. Zdarta, I. Pertenko, Z. Kljajić, T. Leisegang, S.L. Molodtsov, D.C. Meyer, T. Jesionowski, H. Ehrlich, RSC Adv. 4, 61743 (2014)

36. M. Wysokowski, I. Petrenko, A.L. Stelling, D. Stawski, T. Jesionowski, H. Ehrlich, Polymers 7, 235-265 (2015)

37. M. Wysokowski, M. Motylenko, J. Beyer, A. Makarova, H. Stöcker, J. Walter, R. Galli, S. Kaiser, D. Vyalikh, V.V. Bazhenov, I. Petrenko, A.L. Stelling, S.L. Molodtsov, D. Stawski, K.J. Kurzydłowski, E. Langer, M.V. Tsurkan, T. Jesionowski, J. Heitmann, D.C. Meyer, H. Ehrlich, Nano Res. 8, 2288-2301 (2015)

38. I. Petrenko, V.V. Bazhenov, R. Galli, M. Wysokowski, J. Fromont, P.J. Schupp, A.L. Stelling, E. Niederschlag, H. Stöker, V.Z. Kutsova, T. Jesionowski, H. Ehrlich, Int. J. Biol. Macromol. 104, 1626-1632 (2017)

39. H. Ehrlich, E. Steck, M. Ilan, M. Maldonado, G. Muricy, G. Bavestrello, Z. Kljajic, J.L. Carballo, S. Schiaparelli, A. Ereskovsky, P. Schupp, R. Born, H. Worch, V.V. Bazhenov, D. Kurek, V. Varlamov, D. Vyalikh, K. Kummer, V.V. Sivkov, S.L. Molodtsov, H. Meissner, G. Richter, S. Hunoldt, M. Kammer, S. Paasch, V. Krasokhin, G. Patzke, E. Brunner, W. Richter, Int. J. Biol. Macromol. 47, 141-145 (2010)

40. H. Ehrlich, M. Ilan, M. Maldonado, G. Muricy, G. Bavestrello, Z. Kljajic, J.L. Carballo, S. Schiaparelli, A. Ereskovsky, P. Schupp, R. Born, H. Worch, V.V. Bazhenov, D. Kurek, V. Varlamov, D. Vyalikh, K. Kummer, V. Sivkov, S.L. Molodtsov, H. Meissner, G. Richter, E. Steck, W. Richter, S. Hunoldt, M. Kammer, S. Paasch,
V. Krasokhin, G. Patzke, E. Brunner, Int. J. Biol. Macromol. 47, 132-140 (2010)

41. C. Klinger, S. Żółtowska-Aksamitowska, M. Wysokowski, M.V. Tsurkan, R. Galli, I. Petrenko, T. Machałowski, A. Ereskovsky, R. Martinović, L. Muzychka, O.B. Smolii, N. Bechmann, V. Ivanenko, P.J. Schupp, T. Jesionowski, M. Giovine, Y. Joseph, S.R. Bornstein, A. Voronkina, H. Ehrlich, Mar. Drugs 17, 131 (2019)

42. J. Ziętek, L. Guz, S. Winiarczyk, K. Szkucik, M. Ziomek, M. Wysokowski, J. Madany, Ł. Adaszek, Pol. J. Vet. Sci. 21, 445-449 (2018)

43. J. Ziętek, L. Guz, K. Panasiuk, S. Winiarczyk, Ł. Adaszek, Med. Weter. 73, 366-369 (2017)

44. M.S. Fernández, F. Valenzuela, J.I. Arias, J.L. Arias, J. Struct. Biol. J. 196, 187-196 (2016)

45. S. Li, Y. Liu, C. Liu, J. Huang, G. Zheng, L. Xie, R. Zhang, Fish Shellfish Immunol. 51, 263-270 (2016)

46. J. Huang, S. Li, Y. Liu, C. Liu, L. Xie, R. Zhang, Sci. Rep. 8, 4657 (2018)

47. M. Lopes-Lima, I. Ribeiro, R.A. Pinto, J. Machado, Comp. Biochem. Physiol. Part A 141, 319-326 (2005)

48. K. Wilbur, in Physiology of Mollusca, vol. I, ed. by K.M. Wilbur, C.M. Yonge (Academic Press, New York, 1972), pp. 243-282

49. A.S.M. Saleuddin, K.M. Wilbur, Can. J. Zool. 47, 1107-1111 (1969)

50. V.R. Meenakshi, G. Donnay, P.L. Blackwelder, K.M. Wilbur, Calcif. Tissue Res. 15, 31-44 (1974)

51. M. Florek, E. Fornal, P. Gómez-romero, E. Zieba, W. Paszkowicz, J. Lekki, J. Nowak, A. Kuczumow, Mater. Sci. Eng. C 29, 1220-1226 (2009)

52. K. Chong, C. Chia, S. Zakaria, AIP Conf. Proc. 1614, 52 (2014)

Publisher's Note Springer Nature remains neutral with regard to jurisdictional claims in published maps and institutional affiliations. 